\title{
Ultrastructural Study on Colocalization of Glucagon-Like Peptide (GLP)-1 with GLP-2 in Chicken Intestinal L-Cells
}

\author{
Kei NISHIMURA ${ }^{1)}$, Kohzy HIRAMATSU²), Mohammad M. MONIR ${ }^{3)}$, Chihiro TAKEMOTO ${ }^{1)}$ and \\ Takafumi WATANABE ${ }^{2}$ \\ 1) Department of Food Production Science, Graduate School of Agriculture, Shinshu University, 8304 Minami-minowa, Kami-ina, Nagano \\ 399-4598, Japan \\ 2) Laboratory of Animal Functional Anatomy (LAFA), Faculty of Agriculture, Shinshu University, 8304 Minami-minowa, Kami-ina, \\ Nagano 399-4598, Japan \\ ${ }^{3)}$ Department of Bioscience and Food Production Science, Interdisciplinary Graduate School of Science and Technology, Shinshu \\ University, 8304 Minami-minowa, Kami-ina, Nagano 399-4598, Japan
}

(Received 27 February 2013/Accepted 29 May 2013/Published online in J-STAGE 12 June 2013)

ABSTRACT. Colocalization of glucagon-like peptide (GLP)-1 with GLP-2 in L-cells was investigated in the chicken ileum by using double immunofluorescent and immunocytochemical techniques. Ultrastructural features of L-cells were also clarified in this study. L-cells showing immunoreactivity for both GLP-1 and GLP-2 were distributed in the whole ileum. They showed comma-like or flask-like shape and were located in epithelium of crypts and lower part of intestinal villi. L-cells showing GLP-1-immunoreactivity only were found in epithelium of lower and middle parts of intestinal villi. Transmission electron microscopy indicated that L-cells identified by colloidal gold-labeled immunocytochemistry were covered apically with microvilli, open-type and contained many secretory granules in their perikarya. These secretory granules without halo were round to oval in shape and showed moderate electron density. The longest and shortest diameters of secretory granules were $355 \pm 62 \mathrm{~nm}$ (mean $\pm \mathrm{SD}$ ) and $287 \pm 48 \mathrm{~nm}$, respectively. Double labeling immunocytochemistry using two different sizes of particles ( 6 and $12 \mathrm{~nm}$ in diameter) of colloidal gold revealed that GLP-1 colocalized with GLP-2 in the same secretory granules. This study advances new morphological data about the endocrine system of the chicken small intestine. KEY WORDS: chicken, glucagon-like peptides, immunocytochemistry, immunohistochemistry, small intestine.

doi: 10.1292/jvms.13-0106; J. Vet. Med. Sci. 75(10): 1335-1339, 2013

Glucagon-like peptide-1 (GLP-1) is a 30-amino acid peptide derived by specific post-translational proteolytic cleavage and other enzymatic modifications of proglucagon and secreted from $L$ cells in the intestine $[5,17]$. This mealinduced gut hormone [2, 7] has many important physiological actions, such as the accentuation of glucose-dependent insulin release, the inhibition of glucagon secretion and the increase of pancreatic B cell growth [5, 8, 15]. Moreover, GLP-1 has other important biological functions; e.g. reduction of food intake [2,9], deceleration of gastric emptying $[15,18]$ and intestinal motility $[21,22]$. Immunohistochemical and morphometrical studies in the chicken intestine have shown that GLP-1-immunoreactive cells are mainly distributed in the whole jejunum and ileum, and rarely found in ascending duodenum, but not in other intestinal regions $[11,12]$. Pirone et al. showed similar findings about GLP1-immunoreactive cells in the pheasant gastrointestinal tract [16]. These findings suggest that GLP-1 plays an important role in the regulation of activities of the avian small intestine.

GLP-2 is an intestinotrophic peptide consisted of 33-amino acid and has some important effects, such as a stimulation of

\footnotetext{
*Correspondence to: Hiramatsu, K., Laboratory of Animal Functional Anatomy (LAFA), Faculty of Agriculture, Shinshu University, 8304 Minami-minowa, Kami-ina, Nagano 399-4598, Japan. e-mail: seitaik@shinshu-u.ac.jp

(C)2013 The Japanese Society of Veterinary Science
}

the intestinal growth and an inhibition of apoptosis in the intestinal crypt compartment [1]. This hormone is also derived from proglucagon in the intestinal L-cells $[4,5]$, so that these two GLPs are colocalized in the same secretory granule of the mammalian intestinal L-cells [23]. This colocalization, however, is not demonstrated in the chicken intestine.

Enteroendocrine cells are identified by morphological features of their secretory granules. Some ultrastructural studies on intestinal L-cells in the mammalian intestine have revealed that their secretory granules show a round shape of $250-400 \mathrm{~nm}$ in diameter and a high electron density without halo $[3,10,14,23]$. But, no data are obtained about ultrastructural features of L-cells in the chicken intestine as far as we know. Ultrastructural data, especially about secretory granules, may present important informations to understand the mechanisms of GLP secretion. In the present study, we aimed to clarify the colocalization of GLP-1 with GLP-2 in chicken intestinal L-cells by using double immunofluorescent technique and immunocytochemistry with colloidal gold. Ultrastructural characteristics of L-cells were also examined in the chicken small intestine.

\section{MATERIALS AND METHODS}

Experimental birds: White Leghorn chicks ( $\mathrm{n}=12$, male) at one day of age were commercially obtained from Komatsu Shukeijyo (Matsumoto, Japan) and reared in our laboratory given a commercial diet and water ad libitum and under 
controlled light condition (12 hr light: $12 \mathrm{hr}$ darkness) up to one week of age. Chicks were treated in accordance with the "Guideline for Regulation of Animal Experimentation (1997)" of Faculty of Agriculture, Shinshu University.

Tissue samples: Chicks were perfused with a mixture of $4 \%$ paraformaldehyde and $0.01 \%$ glutaraldehyde in phosphate buffer ( $\mathrm{pH} 7.6$ ) following $0.75 \% \mathrm{NaCl}$ solution under anesthesia with diethyl ether. Proximal and distal portions of ileum were immediately dissected out as the tissue samples and then immersed in the same perfusate for $5 \mathrm{hr}$ at $4^{\circ} \mathrm{C}$. Tissue samples were cut into small blocks and pieces and embedded in paraffin wax and epoxy resin, Quetol 812, respectively according to each standard procedure.

Immunofluorescent technique: Paraffin sections cut at 5 $\mu \mathrm{m}$ thickness were treated with $2.5 \%$ normal donkey serum (IHR-8135, ImmunoBioScience, Mukilteo, WA, U.S.A.) for $20 \mathrm{~min}$ and incubated with the mouse monoclonal antibody against synthetic human GLP-1 (aa 7-36 amide) (diluted to 1:2,000, A6104.1, Immunodiagnostik, Bensheim, Germany) for $24 \mathrm{hr}$. After several washing with phosphate buffered saline (PBS), paraffin sections were subsequently incubated with rabbit anti-human ( $\left.\mathrm{Arg}^{34}\right)$-GLP-2 serum (1:500, H-02814, Phenix Pharmaceuticals, Burlingame, CA, U.S.A.) for 24 hr. Incubation of sections with the cocktail of FITC-labeled donkey anti-mouse Ig G (1:100, GTX85337, GeneTex, Irvine, CA, U.S.A.) and rhodamine-labeled donkey anti-rabbit Ig G (1:100, 611-700-127, Rockland Immunochemicals, Gillbertsville, PA, U.S.A.) was carried out for $3 \mathrm{hr}$. Sections were coverslipped with aqueous mounting medium (PermaFluor, Thermo Fisher Scientific, Fremont, CA, U.S.A.), observed and photomicrographed under a fluorescent microscope (AxioImager, Zeiss, Göttingen, Germany). All incubations were carried out in the moisture chamber at room temperature.

The specificities of primary antibodies used in this study were documented by the manufacturers and in previous reports $[6,19]$. Primary antibodies against GLP-1 and GLP-2 mentioned above were preabsorbed with chicken/common turkey GLP-1(7-36) amide $\left(10^{-6} \mathrm{M} / \mathrm{ml}, \mathrm{H}-5824\right.$, Bachem, Bubendorf, Switzerland) at $4^{\circ} \mathrm{C}$ for $24 \mathrm{hr}$ and then used for confirming the specificities of them. Preabsorbed GLP-1 monoclonal antibody showed the negative reaction, but preabsorbed GLP-2 antiserum did the specific immunoreactivity. Moreover, single immunofluorescent staining was carried out for each primary antibody and compared with double immunofluorescent staining. Negative control sections were incubated with the normal donkey serum instead of the specific primary antibody or in the absence of the primary antibody. They showed negative immunoreactivity. Paraffin sections from rat ileum were used for positive control sections and showed the specific immunoreactivity for each primary antibody. The specificity of the secondary antiserum was controlled by the omission of the primary antibody. No cross reactivity of the secondary antiserum was observed.

Immunocytochemistry: Ultrathin sections were made with an ultramicrotome (Super Nova, Reichert-Jung, Vienna, Austria) by using glass knives and mounted on nickel grids.
Ultrathin sections, pretreated with $1 \%$ sodium periodate solution and $1 \%$ normal donkey serum subsequently, were incubated with the mouse monoclonal antibody against GLP-1 (1:8,000) overnight. After several washing with PBS, they were treated with colloidal gold (12 $\mathrm{nm}$ in diameter)labeled donkey anti-mouse Ig G serum (1:200, 715-205-150, Jackson Immuno Research, West Grove, PA, U.S.A.) for 2 hr, stained with TI blue (Nisshin-EM, Tokyo, Japan) and observed under a transmission electron microscope (JEM1400, JEOL, Tokyo, Japan).

Double immunocytochemical staining was applied for the detection of colocalization of GLP-1 with GLP-2 at electron microscopic level. After incubation with the monoclonal antibody against GLP-1, sections were subsequently incubated with rabbit anti-GLP-2 serum (1:2,000). And then, ultrathin sections were treated with a mixture of colloidal gold (12 $\mathrm{nm}$ in diameter)-labeled donkey anti-mouse Ig G serum mentioned above and colloidal gold (6 $\mathrm{nm}$ in diameter)labeled donkey anti-rabbit Ig G serum (1:200, 711-205-152, Jackson Immuno Research) for $2 \mathrm{hr}$, stained with TI blue and observed under a transmission electron microscope. All incubations were carried out in the moisture chamber at room temperature. The specificity of the colloidal goldlabeled secondary antiserum was controlled by the omission of the primary antibody. No cross reactivity of the secondary antiserum was observed.

Morphometry: Morphometrical analysis was carried out to characterize secretory granules of L-cells. The shortest and longest diameters of secretory granules were measured by using an image analyzer (KS400, Carl Zeiss, Göttingen, Germany). Photomicrographs at $\times 5,000$ magnification were used for this measurement. A total of 160 secretory granules from $10 \mathrm{~L}$-cells were measured.

\section{RESULTS}

Single immunofluorescent staining for GLP-1 and GLP-2 revealed that endocrine cells showing immunoreactivity for each peptide were scattered in the villous epithelium and crypt of the chicken ileum (Fig. 1a and 1b). Both immunoreactive cells showed the similar localization in the ileum to that indicated by double immunofluorescent staining as mentioned below and our previous observation.

L-cells showing immunoreactivity for both GLP-1 and GLP-2 were observed in the whole ileum (Figs. 1c, 1c' and 2 ). They were located in epithelium of crypts and lower part of intestinal villi and showed comma-like or flask-like shape (Fig. 2, large arrows). These cells had a long cytoplasmic process (Fig. 2a, small arrow) and were in contact with the intestinal lumen. L-cells showing immunoreactivity for only GLP-1 were located in epithelium of lower and middle parts of intestinal villi (Fig. 2a, arrowhead). Most of GLP2-immunoreactive cells were also immunoreactive for GLP1 (Fig. 1c and 1c').

At the electron microscopic level, L-cells labeled with gold particles of $12 \mathrm{~nm}$ in diameter were found in epithelium of crypts and lower and middle parts of intestinal villi (Fig. $3 \mathrm{a}$ and $3 \mathrm{c}$ ). Gold particles were mainly found on secretory 


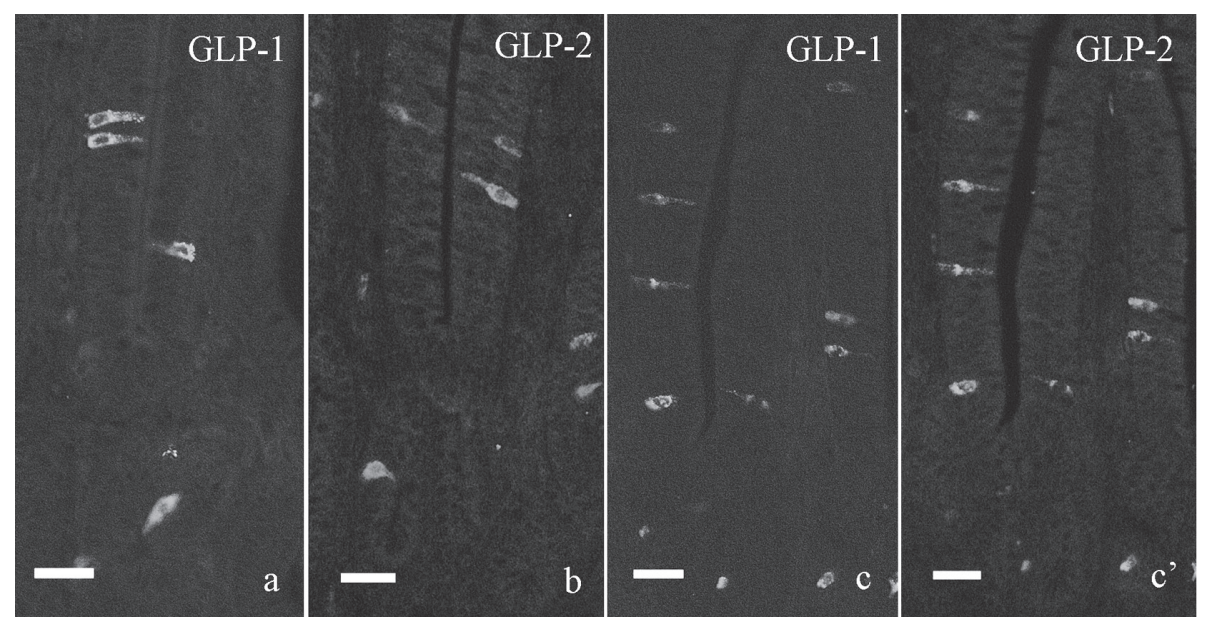

Fig. 1. Immunofluorescent staining for GLP-1 (a, c) and GLP-2 (b, c') in the chicken distal ileum. a, b: Single immunofluorescent staining for GLP-1 (a) and GLP-2 (b). Both immunoreactive cells are scattered in villous epithelium and crypt of the distal ileum and show the similar localization to that indicated by double immunofluorescent staining. c, c': Double immunofluorescent staining for GLP1 (c) and GLP-2 (c'). Most GLP-1-immunoreactive cells also show immunoreactivity for GLP-2. $\mathrm{Bar}=20 \mu \mathrm{m}$.

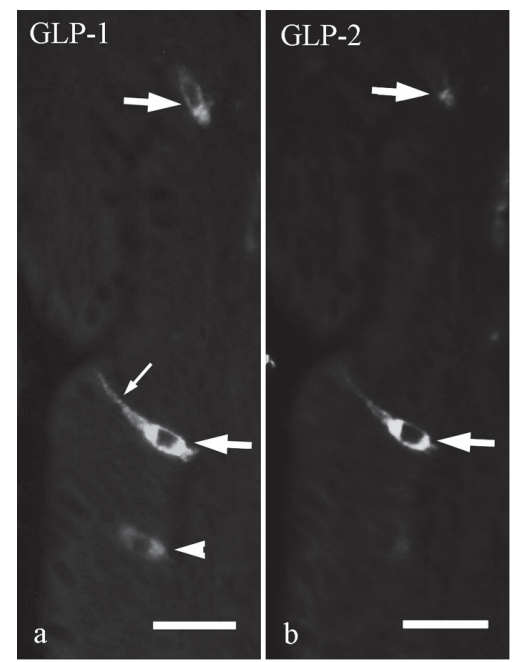

Fig. 2. Double immunofluorescent staining for GLP1 (a) and GLP-2 (b) in villous epithelium of the chicken distal ileum. L-cells showing immunoreactivity for both GLP-1 and GLP-2 have a long cytoplasmic process (small arrow) and are in contact with intestinal lumen (large arrows). Arrowhead indicates L-cell showing immunoreactivity only for GLP-1. Bar $=20 \mu \mathrm{m}$.

granules, but rarely on cytosol or other organelles. L-cells were flask-like or comma-like in shape (Fig. 3a and 3c) and had an oval nucleus. They were covered apically with microvilli, so-called open-type endocrine cells. Their secretory granules without halo were accumulated mainly in the basal cytoplasm of L-cells. They were round to oval in shape and labeled with gold particles of $12 \mathrm{~nm}$ in diameter (Fig. $3 \mathrm{~b}$ and 3d). They showed lower electron-density than that of secretory granules in enterochromaffine (EC) cells. EC cells having polymorphous secretory granules with the high electron density were observed in the intestinal epithelium, but gold particles were not located on their secretory granules (Fig. $3 \mathrm{e})$. Morphometrical analysis indicated that the shortest and longest diameters of secretory granules of L-cells were 355 $\pm 62 \mathrm{~nm}($ mean $\pm \mathrm{SD})$ and $287 \pm 48 \mathrm{~nm}$, respectively.

Double immunocytochemistry showed that secretory granules of L-cells labeled with gold particles of $12 \mathrm{~nm}$ in diameter were also labeled with those of $6 \mathrm{~nm}$ in diameter, showing GLP-2 immunoreactivity. These two sizes of gold particles were diffusely arranged on secretory granules (Fig. 3d) and rarely observed on cytosol or other organelles. The ratio between these two sizes of gold particles was almost equal on a secretory granule of L-cells.

\section{DISCUSSION}

The present study clarified the colocalization of GLP-1 with GLP-2 as well as ultrastructural features of L-cells in the chicken small intestine by colloidal gold-labeling immunocytochemistry. L-cells in the chicken small intestine are characterized by microvilli covering their apical surface and many secretory granules showing moderate electron density. Secretory granules without halo are relatively large and round or oval in shape, and GLP-1 and GLP-2 are stored in them. Our previous studies at the light microscopic level have reported the morphological features and the distributional pattern of GLP-1-immunoreactive cells in the chicken small intestine $[11,12]$. According to these studies, GLP1-immunoreactive cells show comma-like or flask-like shape and are in contact with the intestinal lumen by their apical cytoplasmic process. In the present study, at the elec- 


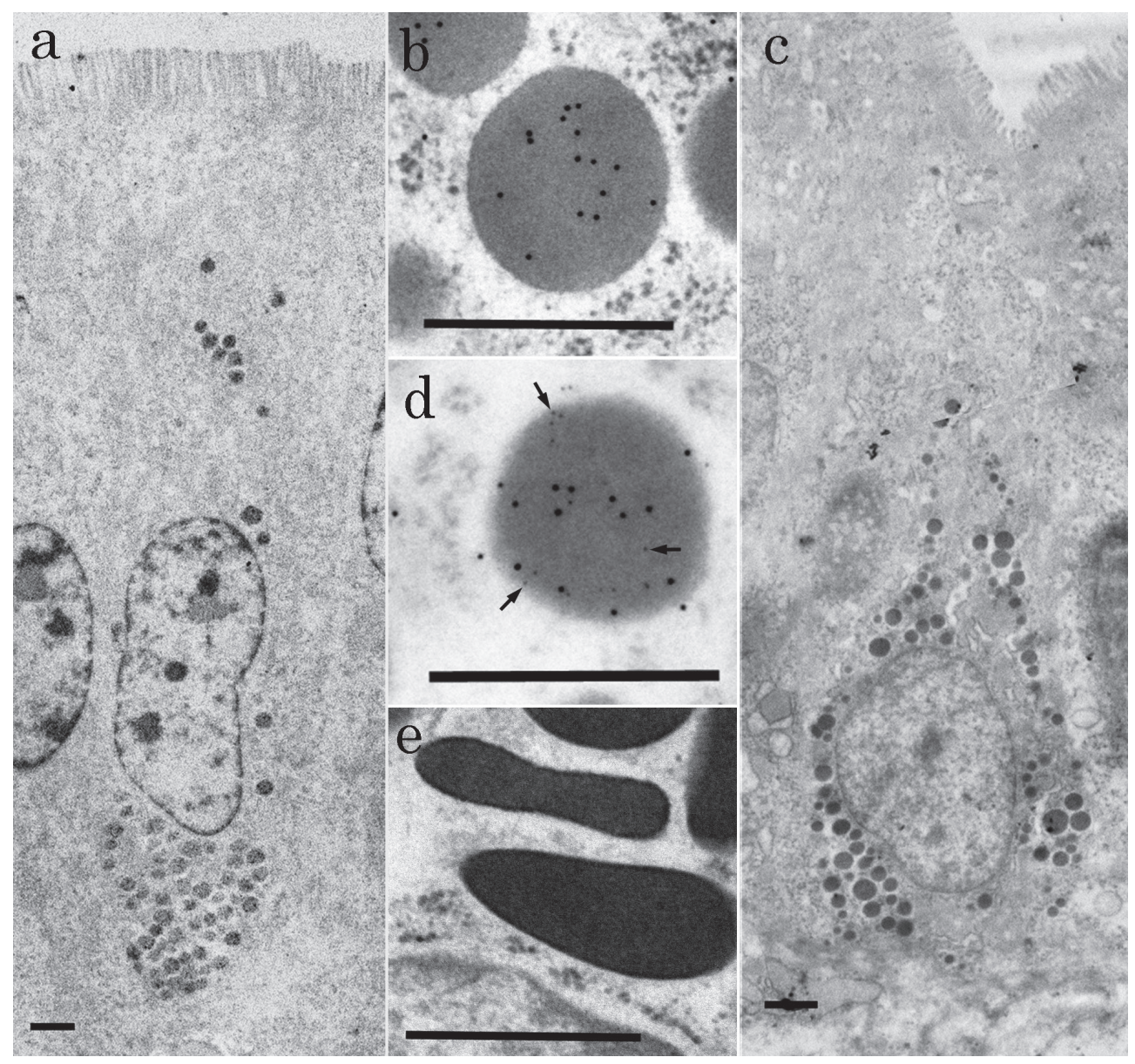

Fig. 3. Electron micrographs of L-cells in the chicken distal ileum. (a) Low magnification view of L-cell showing GLP-1-immunoreactivity and located in villous epithelium. Note that its apical surface is covered with microvilli. Bar $=1 \mu \mathrm{m}$. (b) High magnification view of a secretory granule from L-cell. Particles of colloidal gold (12 nm in diameter) are diffusely arranged on a granule. Bar $=0.5 \mu \mathrm{m}$. (c) Low magnification view of L-cells showing GLP-1 and -2-immunoreactivity and located in epithelium of crypt. Bar=1 $\mu \mathrm{m}$. (d) High magnification view of a secretory granule from L-cell. Both sizes of particles of colloidal gold ( 6 and $12 \mathrm{~nm}$ in diameter) are diffusely arranged on a granule. Arrows indicate gold particles of $6 \mathrm{~nm}$ in diameter. Bar $=0.5 \mu \mathrm{m}$. (e) High magnification view of secretory granules of EC cell in chicken small intestine. These granules are polymorphous and show high electron density. Bar $=0.5 \mu \mathrm{m}$.

tron microscopic level, we also revealed that L-cells come into contact with the intestinal lumen by microvilli covering their apical surface. These findings indicate that L-cells are namely open-type of endocrine cells and receive chemical signals in the intestinal lumen, such as digests of ingested meal. In fact, GLP-1 is released in response to food intake and exerts its physiological actions in mammals [2, 7]. Our finding suggests that GLP-1 is the meal-induced hormone also in the chicken.

Enteroendocrine cells have been classified into several types according to morphological features, e.g. shape, size and electron density of their secretory granules [13]. Some ultrastructural studies in the mammalian intestine have shown that L-cells are characterized by round, homogenous, large (about $300 \mathrm{~nm}$ in diameter) and electron-dense granules [3, $10,14,23]$. In the present study, L-cells in the chicken intes- tine were also characterized with secretory granules showing similar features to those in mammalian L-cells mentioned above. Electron density of secretory granules in chicken L-cells, however, is not similar to those in mammals. We identified EC cells together with L-cells in this study and found that these EC cells contained polymorphous and electron dense granules as reported in the previous study in the chicken duodenum [24]. Compared with secretory granules in EC cells, those in L-cells were lower electron density and showed moderate density. This difference in electron density of secretory granules is likely to be one of characteristic features of chicken intestinal L-cells.

The present study revealed the colocalization of GLP-1 with GLP-2 in the same cells. Human GLP-2 is a gastrointestinal hormone with $33 \%$ sequence homology to glucagon and shows the intestinotrophic endocrine/paracrine actions 
[20]. This peptide, consisting of 33-amino acids, is derived from proglucagon by its posttranslational processing and secreted from intestinal L-cells. Thus, two forms of GLP, GLP-1 and -2 , are synthesized from the same precursor and secreted from the same cells in the mammalian intestine. Our immunocytochemical findings provide the prediction of cosecretion of GLP-1 with GLP-2 from the same L-cells also in the chicken small intestine. A double immunofluorecent study demonstrated that L-cells showing the colocalization of GLP-1 with GLP-2 were mainly located in epithelium of crypts and lower part of villi of chicken small intestine. Moreover, L-cells showing immunoreactivity for GLP-1 only were observed in epithelium of lower and middle parts of villi. Considering these findings at electron and light microscopic levels, it is possible that GLP-1 and -2 are costored in the same secretory granules, but secreted from the same L-cells separately.

In conclusion, L-cells in the chicken small intestine are characterized with microvilli covering their apical surface and large secretory granules showing moderate electron density. Colocalization of GLP-1 with GLP-2 in the same L-cells is also demonstrated, but it is suggested that these two hormones are secreted from the same cells separately.

ACKNOWLEDGMENT. This study was supported in part by Grant-in-Aid from Kieikai Research Foundation.

\section{REFERENCES}

1. Baggio, L. L. and Drucker, D. J. 2004. Glucagon-like peptide-1 and glucagon-like peptide-2. Best Pract. Res. Clin. Endocrinol. Metab. 18: 531-554. [Medline] [CrossRef]

2. Balkan, B. 2000. Effects of glucagon-like peptide-1 (GLP-1) on glucose homeostasis and food intake. Appetite 35: 269-270. [Medline] [CrossRef]

3. Buffa, R., Capella, C., Fontana, P., Usellini, L. and Solchia, E. 1978. Types of endocrine cells in the human colon and rectum. Cell Tissue Res. 192: 227-240. [Medline] [CrossRef]

4. Burrin, D. G., Stoll, B. and Guan, X. 2003. Glucagon-like peptide 2 function in domestic animals. Domest. Anim. Endocrinol. 24: 103-122. [Medline] [CrossRef]

5. Drucker, D. J. 2006. The biology of incretin hormones. Cell Metab. 3: 153-165. [Medline] [CrossRef]

6. Eissele, R., Göke, R., Willemer, H. P., Vermeer, H., Amold, R. and Göke, B. 1992. Glucagon-like peptide-1 cells in the gastrointestinal tract and pancreas of rat, pig and man. Eur. J. Clin. Invest. 22: 283-291. [Medline] [CrossRef]

7. Elliott, R. M., Morgan, L. M., Tredger, J. A., Deacon, S., Wright, J. and Marks, V. 1993. Glucagon-like peptide-1(7-36)amide and glucose-dependent insulinotropic polypeptide secretion in response to nutrient ingestion in man: acute post-prandial and 24-h secretion patterns. J. Endocrinol. 138: 159-166. [Medline] [CrossRef]

8. Fridolf, T., Böttcher, G., Sundler, F. and Ahrén, B. 1991. GLP-1 and GLP-1(7-36) amide: influence on basal and stimulated insulin and glucagon secretion in the mouse. Pancreas 6: 208-215. [Medline] [CrossRef]

9. Furuse, M., Matsumoto, M., Okumura, J., Sugahara, K. and Hasegawa, S. 1997. Intracerebroventricular injection of mammalian and chicken glucagon-like peptide-1 inhibits food intake of the neonatal chick. Brain Res. 755: 167-169. [Medline] [CrossRef]
10. Garaud, J. C., Eloy, R., Moody, A. J., Stock, C. and Grenier, J. F. 1980. Glucagon- and Glicentin-immunoreactive cells in the human digestive tract. Cell Tissue Res. 213: 121-136. [Medline] [CrossRef]

11. Hiramatsu, K., Yamasaki, A. and Karasawa, Y. 2003. Comparative study on the distribution of glucagon-like peptide-1 (GLP-1)-immunoreactive cells in the intestine of chicken and ostrich. J. Poult. Sci. 40: 39-44. [CrossRef]

12. Hiramatsu, K., Yamasaki, A. and Shioji, T. 2005. Immunohistochemical and morphometrical studies on the distribution of glucagon-like peptide-I (GLP-I)-immunoreactive cells in the chicken intestine. J. Poult. Sci. 42: 223-229. [CrossRef]

13. Kobayashi, S., Fujita, T. and Sasagawa, T. 1970. The endocrine cells of human duodenal mucosa. An electron microscope study. Arch. Histol. Jpn. 31: 477-494. [Medline] [CrossRef]

14. Lehy, T., Peranzi, G. and Cristina, M. L. 1981. Correlative immunocytochemical electron microscopic studies: Identification of (entero)glucagon- somatostatin- and pancreatic polypeptidelike-containing cells in the human colon. Histochemistry 71: 67-80. [Medline] [CrossRef]

15. Nauck, M. A. 1998. Glucagon-like peptide 1 (GLP-1): a potent gut hormone with a possible therapeutic perspective. Acta Diabetol. 35: 117-129. [Medline] [CrossRef]

16. Pirone, A., Ding, B. A., Giannessi, E., Coli, A., Strornelli, M. R., di Cossato, M. M. F., Piano, I. and Lenzi, C. 2012. Glucagon-like peptide 1 (GLP-1) in the gastrointestinal tract of the pheasant (Phasianus colchicus). Acta Histochem. 114: 535-539. [Medline] [CrossRef]

17. Richards, M. P. and McMurtry, J. P. 2009. The avian proglucagon system. Gen. Comp. Endocrinol. 163: 39-46. [Medline] [CrossRef]

18. Schirra, J., Nicolous, M., Roggel, R., Katschinski, M., Storr, M., Woerle, H. J. and Göke, B. 2006. Endogenous glucagon-like peptide 1 controls endocrine pancreatic secretion and antro-pyloro-duodenal motility in humans. Gut 55: 243-251. [Medline] [CrossRef]

19. Theodorakis, M. J., Carlson, O., Michopoulos, S., Doyle, M. E., Juhaszova, M., Petraki, K. and Egan, J. M. 2006. Human duodenal enteroendocrine cells: source of both incretin peptides, GLP-1 an GIP. Am. J. Physiol. Endocrinol. Metab. 290: E550E559. [Medline] [CrossRef]

20. Thulesen, J. 2004. Glucagon-like peptide 2 (GLP-2), an intestinotrophic mediator. Curr. Protein Pept. Sci. 5: 51-65. [Medline] [CrossRef]

21. Tolessa, T., Gutniak, M., Holst, J. J., Efendic, S. and Hellström, P. M. 1998. Glucagon-like peptide-1 retards gastric emptying and small bowel transit in the rat. Dig. Dis. Sci. 43: 2284-2290. [Medline] [CrossRef]

22. Tolessa, T., Gutniak, M., Holst, J. J., Efendic, S. and Hellström, P. M. 1998. Inhibitory effect of glucagon-like peptide-1 on small bowel motility. Fasting but not fed motility inhibited via nitric oxide independently of insulin and somatostatin. J. Clin. Invest. 102: 764-774. [Medline] [CrossRef]

23. Varndell, I. M., Bishop, A. E., Sikri, K. L., Uttenthal, L. O., Bloom, S. R. and Polak, J. M. 1985. Localization of glucagonlike peptide (GLP) immunoreactants in human gut and pancreas using light and electron microscopic immunocytochemistry. $J$. Histochem. Cytochem. 33: 1080-1086. [Medline] [CrossRef]

24. Watanabe, T., Chikazawa, H., Chungsamarnyart, N., Fujioka, T. and Yamada, J. 1987. Serotonin-storing cells of the chicken duodenum: light, fluorescence and electron microscopy, and immunohistochemistry. Cell Tissue Res. 247: 25-32. [Medline] [CrossRef] 